ISSN 0258-7122 (Print), 2408-8293 (Online)

Bangladesh J. Agril. Res. 44(1): 43-58, March 2019

\title{
ECONOMIC ANALYSIS OF TURMERIC CULTIVATION: EVIDENCE FROM KHAGRACHARI DISTRICT
}

\author{
M. E. A. BEGUM ${ }^{1}$, M. A. MONAYEM Miah ${ }^{2}$, M. A. RASHID \\ M. T. ISLAM ${ }^{4}$ AND M. I. HOSSAIN ${ }^{5}$
}

\begin{abstract}
Turmeric is a good source of income for hilly people of Bangladesh. The study estimated the profitability and technical efficiency of turmeric cultivation in Khagrachhari district. In total 150 turmeric farms located in Khagrachari Sadar, Panchari and Matiranga Upazilas of Khagrachari district, were surveyed. Data were collected, using a pre-tested questionnaire during January, 2015. The study revealed that turmeric farming is a profitable farming with some dominating variable costs like seed (rhizome) and sowing, harvesting and carrying. As the net return was Tk. 112139 per hectare and the BCR of sampled farmers was 2.20 , this indicates that turmeric farms with a BCR greater than 1 have greater benefits than costs as well as positive net benefits. Seed (rhizome) and fertilizer showed significant positive effects on the turmeric production in the stochastic frontier production model. Turmeric farming displayed a mean technical efficiency of $82 \%$, which suggested a substantial $18 \%$ of potential output of turmeric can be recovered by removing inefficiency. Besides improving technical efficiency, potential also exists for raising turmeric production through higher education and extension services. For a land scarce country like Bangladesh this gain could help increase income and ensure better livelihood for the hilly farmers. The policy implication of the analysis is that investment in education and extension service would greatly improve technical efficiency that contribute to income of the hilly people.
\end{abstract}

Keywords: Turmeric cultivation, cost and return, profitability, technical efficiency.

\section{Introduction}

Turmeric (Curcuma longa L.) is a spice made from the roots of Turmeric plant referred as "Queen of Spices". It has been listed as one of the top five major spices in Bangladesh which shares about $6 \%$ of total spices production (BBS, 2018). It has diversified uses. The people of Bangladesh usually use turmeric in all curry preparation like meat, fish, vegetables, pulses etc. for its typical color and flavor. Besides, it is used in medicine and cosmetics and as dye in textile

${ }^{1}$ Senior Scientific Officer, Agricultural Economics Division, Bangladesh Agricultural Research Institute (BARI), Joydebpur, Gazipur-1701, ${ }^{2 \& 3}$ Principal Scientific Officer, Agricultural Economics Division, BARI, Joydebpur, Gazipur-1701, ${ }^{4}$ Scientific Officer, Pomology Division, Horticulture Research Centre (HRC), BARI, Joydebpur, Gazipur1701, ${ }^{5}$ Professor, Department of Agribusiness and Marketing, Bangladesh Agricultural University, Mymensingh-2202, Bangladesh. 
industries from the time immemorial. It contents about $69.43 \%$ carbohydrate, $6.30 \%$ protein, $5.10 \%$ oil and $3.50 \%$ mineral and other important element in dry turmeric (BBS, 2013 ).With increased awareness on the benefits of turmeric among the users and its use in a number of processed products, the demand of turmeric is increasing.

Turmeric can be regarded as a good cash crop for hilly regions of Bangladesh as its production requires low technology, less capital investment, and it can be grown with comparatively less use of fertilizer. The sloppy topography of hilly region and the nature of soil are optimal for turmeric cultivation as it allows no accumulation of water. Usually, turmeric is grown in those lands where other horticulture crops and grains do not grow properly. Regarding the production of turmeric in the hill areas, it has greater scope of expansion in terms of area and production as the current production is mostly for domestic consumption. The production area can be extended by the farmers having marginal land, which will be beneficial for them in terms of earning extra income from the sales of the crop. Turmeric has also import substitution potential as the country is importing various turmeric products from India and other neighboring countries.

In 2003-04, the total area under turmeric farming was estimated to be around 45 thousand acres (with production of 70 thousand tons), while in 2011-12 it was 60 thousand acres (with production of 149 thousand tons), which indicates an average increase of area of 33\% per annum (BBS, 2013b). This level of expansion reflects the government's priorities as turmeric farming is recognized as an essential component of economic development for the country. In spite of the spectacular expansion of turmeric farming during the last decades, still the average yield ( 2.5 ton/ha as dry matter) is low compared to other Asian countries (BBS, 2013). The reasons behind such low yield due to lack of high yielding varieties and inadequate adoption of improved technologies followed by the local growers.

Developing economy of Bangladesh can benefit a great deal from inefficiency studies, which shows that it is still possible to raise productivity by improving efficiency. Estimates on the extent of inefficiency can also help to decide whether to improve efficiency or to develop new technology. Moreover, efficiency of a farm refers to its performance in the utilization of resources at its disposal. Thus, it is important to know how well the resources are being utilized and what possibilities exist for improving the production using the existing resources and technology (Ahluwalia, 1996). Therefore, the main objective in this study was to evaluate profitability and technical efficiency in an attempt to modify the management strategy and increase turmeric farming productivity in Khagrachari district of Bangladesh. In the context of Bangladesh agriculture, a number of studies emerged to estimate the efficiency of agricultural production at the farm level. Almost all these estimates are related to the efficiency of rice, fish, and spices farms indifferent seasons (Backman et al., 2011, Alam et al., 
2011, and Islam et al. 2011).No attempt has been made to measure the efficiency of the crop like turmeric. It is with this backdrop, that a stochastic production frontier with a technical inefficiency model is applied to investigate profitability and the technical efficiency and the factors affecting production inefficiency of turmeric farming in Khagrachari district. This study is expected to generate information that will be useful for farmers in choosing better production techniques, for identifying and eliminating inefficiencies, and for attaining the highest possible efficiency within the resource endowments. Keeping mind this study aims to: i) to find out the productivity and profitability of turmeric cultivation in the hill areas; ii) to estimate the technical efficiency of the turmeric growers; iii) to identify the factors causing technical inefficiency of turmeric growers; iv) to identify the constraints to turmeric cultivation and v) to suggest some policy implications for its further improvement.

\section{Methodology}

\section{Selection of the study area and sampling procedure}

The study was carried out in Khagrachari district which is one of the major turmeric growing districts in Bangladesh. It accounted for $8.9 \%$ of the total turmeric area. A stratified random sample was constructed by dividing the district into Upazila and village. Khagrachari district consists of eight Upazilas: Dighinala, Khagrachari Sadar, Laxshmichhari, Mahalchhari, Manikchhari, Matiranga, Panchhari and Ramgarh. Among these eight Upazilas Khagrachari Sadar, Matiranga and Panchhari were purposively selected for the study. These Upazilas were identified as the most important areas for turmeric farming. In 2010-11, a total of 2039 acres of land was cultivated for turmeric in these Upazilas which is around $41 \%$ of cultivated area of turmeric in Khagrachari district (BBS, 2013). Within each of these three Upazilas, two villages were randomly selected based on a complete list of villages. Within each village 20-33 households were randomly selected from the list provided by Sub Assistant Agriculture Officer, Department of Agriculture Extension office. This procedure gave a total sample of 150 households involved in turmeric cultivation in Khagrachari district.

\section{Data collection}

The data for this study were collected both from primary and secondary sources. The primary data were collected from the selected farmers for the whole year of 2014. The formal data, however, were collected during January 2015 by using face to face interview technique with the help of a pre-designed and pre-tested questionnaire. The main information gathered includes general household information like household size, age and education level, farming activities, experience with turmeric cultivation, use of inputs including land, labour (both 
family and hired labour), seeds, fertilizers and pesticides, yields and prices of turmeric, perceptions on constraints to increased turmeric productivity etc. The secondary data were collected from different published and unpublished sources, internet browsing, BBS, Agricultural Statistical Yearbooks, etc.

\section{Data analysis}

Gross return: Gross return was calculated by multiplying the total volume of production of an enterprise by the average farmgate prices of that product in the harvesting period (Dillon and Hardaker, 1993). The following equation was used to calculate gross return:

$$
\mathrm{GR}=\sum \mathrm{Q}_{\mathrm{m}} \times \mathrm{P}_{\mathrm{m}}+\sum \mathrm{Q}_{\mathrm{j}} \times \mathrm{P}_{\mathrm{j}}
$$

Where, $\mathrm{GR}=$ Gross return $(\mathrm{Tk} / \mathrm{ha}), \mathrm{Qm}=$ Quantity of turmeric $(\mathrm{kg} / \mathrm{ha}), \mathrm{Pm}=\mathrm{Per}$ unit price $(\mathrm{Tk} / \mathrm{kg})$ of turmeric, $\mathrm{Qj}=\mathrm{Quantity}$ of other Jhum crops $(\mathrm{kg} / \mathrm{ha}), \mathrm{Pj}=$ Per unit price $(\mathrm{Tk} / \mathrm{kg})$ of other Jhum crops.

Total cost: Total cost (TC) included all types of variable and fixed cost items involved in the production process. The total cost was estimated as: $\mathrm{TC}=\Sigma \mathrm{Px}_{\mathrm{i}} \times$ $X_{i}+$ TFC where, $T C=$ Total cost $(\mathrm{Tk} / \mathrm{ha}), X_{i}=$ Quantity $(\mathrm{kg} / \mathrm{ha})$ of the $\mathrm{i}^{\text {th }}$ variable input, Pxi $=$ Per unit price $(\mathrm{Tk} / \mathrm{kg})$ of the $\mathrm{i}^{\text {th }}$ variable input, $\mathrm{TFC}=$ Total fixed cost, which included land use cost.

Computation of farmers' profit: Farmers' profits were calculated in two ways by (a) gross margin (GM) analysis and (b) net return (NR) estimation with the following two equations:

a) $\mathrm{GR}=\sum \mathrm{Q}_{\mathrm{m}} \times \mathrm{P}_{\mathrm{m}}+\sum \mathrm{Q}_{\mathrm{j}} \times \mathrm{P}_{\mathrm{j}}-\sum \mathrm{Px}_{\mathrm{i}} \times \mathrm{X}_{\mathrm{i}}$

b) $\mathrm{NR}=\sum \mathrm{Q}_{\mathrm{m}} \times \mathrm{P}_{\mathrm{m}}+\sum \mathrm{Q}_{\mathrm{j}} \times \mathrm{P}_{\mathrm{j}}-\sum \mathrm{Px}_{\mathrm{i}} \times \mathrm{X}_{\mathrm{i}}-\mathrm{TFC}$

\section{Econometric analysis}

Farrell (1957) defined technical efficiency as the ratio between inputs per unit of output at the production frontier and inputs per unit of output in the observed case. Aigner et al., (1977) and Meeusen and Van den Broeck (1977) independently proposed a stochastic frontier production function model with the following structure:

$$
\begin{aligned}
& \operatorname{Ln} Y=f\left(X_{i} ; \beta\right)+\varepsilon_{i} \\
& \varepsilon_{i}=V_{i}-U_{i}, i=1, \ldots, N_{i}
\end{aligned}
$$

Where, $Y$ denotes production level, $X_{i}$ is input level and $\beta$ is a vector of unknown parameters to be estimated. $\varepsilon_{i}$ is the composed error term and $f$ is the CobbDouglas function form. $V_{i}$ are independently and identically distributed random 
errors, having $\mathrm{N}\left(0, \delta \mathrm{v}^{2}\right)$ distribution while $\underline{U}_{i}$ are non-negative stochastic variables, called technical inefficiency effect, associated with the technical inefficiency of production of farmers involved. According to Battese and Coelli (1995), technical inefficiency effects are defined by

$$
U_{i}=Z_{i} \delta+W_{i}, i=1, \ldots N
$$

where $Z_{i}$ is a vector of explanatory variables associated with technical inefficiency effects, $\delta$ is a vector of unknown parameters to be estimated, $\mathrm{W}_{\mathrm{i}}$ are unobservable random variables, which are assumed to be identically distributed, obtained by truncation of the normal distribution with mean zero and unknown variance $\sigma^{2}$, such that $U_{i}$ are non-negative. In this study the ML was applied, using the FRONTIER 4.1.1 computer program developed by Coelli (1994). The following model specifications were used in the analysis

$$
\operatorname{In} Y_{i}=\beta+\beta_{1} \operatorname{In} X_{1 i},+\beta_{2} \operatorname{In} X_{2 i},+\beta_{3} \operatorname{In} X_{3 i},+\beta_{4} \operatorname{In} X_{4 i}+V_{i}-U_{i}
$$

Where, In represents the natural logarithm (i.e., to the base e) and i refers to the ith farm in the sample; $Y_{i}$ represents geometric mean based on revenue share of multi-output (such as turmeric production, other crops and vegetable production) which is an ideal output variable in the production frontier analysis as suggested by Iinuma et al.,(1999);

$\mathrm{X}_{1 \mathrm{i}}$ represents the total area of land/farm size in hectares; $\mathrm{X}_{2 \mathrm{i}}$ represents the total quantity of labour employed in man-days per hectare per year; $X_{3 i}$ represents total number of turmeric seed used (rhizome) per hectare per year; $\mathrm{X}_{4 \mathrm{i}}$ represents quantity of fertilizer used in $\mathrm{kg}$ per hectare per year; $\mathrm{V}_{\mathrm{i}}$ represents the random variations in output due to factors outside the control of the farm operator such as: natural disaster, disease of turmeric etc. and $\beta_{1}-\beta_{4}$ are parameters to be estimated;

Following Battese and Coelli (1995), it is further assumed that the technical inefficiency distribution parameter, Ui is a function of various operational and farm specific variables hypothesized to influence technical inefficiencies as:

$U_{i}=\beta_{0}+\beta_{1} Z_{1 i},+\beta_{2} Z_{2 i},+\beta_{3} Z_{3 i}+\beta_{4} Z_{4 i}+\delta_{5} Z_{5 i}+W_{i}$

Where, $Z_{1}$ denotes the age of the ith farmer (in year); $Z_{2 i}$ denotes the education (year of schooling) of the ith farmer; $Z_{3 i}$ denotes experience in turmeric farming of the ith farmer (in years); $Z_{4 i}$ denotes the training received by the ith farmer ( 1 if received, 0 otherwise); $Z_{5 i}$ denotes farm visits by extension officers ( 1 if yes, 0 otherwise); $\delta_{1}, \delta_{2}, \delta_{3}, \delta_{4}$, and $\delta_{5}$ are unknown parameters to be estimated. 


\section{Results and Discussion}

\section{Cost of turmeric cultivation}

The cost of turmeric production relates to the level of inputs, the price of inputs, the cultivation systems and the institutional factors such as costs of credit and marketing (Shang and Tisdell, 1997). For this study, data on yield, costs and returns of turmeric were collected to clarify production costs and to assess the profitability. Production costs have been grouped into variable costs and fixed costs.

Variable costs are directly related to the scale of farm operations at any given time. Variable costs in turmeric farm are cost of seed (rhizome), labour, fertilizer, plant protection chemical and interest on working capital. The average annual variable costs of turmeric farming was Tk. 77351 per ha (Table 1).

Table 1.Average variable cost $(\mathrm{Tk} / \mathrm{ha})$ of turmeric cultivation in Khagrachari district

\begin{tabular}{r|l|c|c|c|c|c}
\hline S/No & \multicolumn{1}{|c|}{ Particulars } & $\begin{array}{c}\text { Material } \\
\text { input } \\
\text { (Qty/ha) }\end{array}$ & $\begin{array}{c}\text { Material } \\
\text { input } \\
\text { (Tk./ha) }\end{array}$ & $\begin{array}{c}\text { Human } \\
\text { labour } \\
\text { (Tk./ha) }\end{array}$ & $\begin{array}{c}\text { Total cost } \\
\text { (Tk./ha) }\end{array}$ & Percentage \\
\hline 1 & & & & 8383.44 & 8383.44 & 10.84 \\
2 & Trench & & & 5489.85 & 5489.85 & 7.10 \\
3 & $\begin{array}{l}\text { Seed (Rhizome) and } \\
\text { sowing }\end{array}$ & 652.87 & 15756.71 & 8967.61 & 24724.32 & 31.96 \\
5 & Fertilizer (Kg/ha) & 362.50 & 5747.34 & 1026.84 & 6774.18 & 8.76 \\
6 & $\begin{array}{l}\text { Intercultural operation } \\
\text { (hoeing, weeding) }\end{array}$ & -- & -- & 13686.58 & 13686.58 & 17.69 \\
& & & & & \\
7 & $\begin{array}{l}\text { Plant protection chemical } \\
8\end{array}$ & -- & 330.99 & 159.71 & 490.70 & 0.63 \\
10 & Harvesting and carrying & -- & -- & 15618.07 & 15618.07 & 20.19 \\
& $\begin{array}{l}\text { Interest on working capital } \\
\text { Total variable cost }\end{array}$ & -- & -- & -- & 2183.61 & 2.82 \\
\hline
\end{tabular}

Source: Calculated from field survey (2015)

Seed (rhizome) is the most important cost item for turmeric farming. The average annual cost of rhizome in turmeric farming was calculated to be Tk. 15757 per ha. In turmeric farming the highest operation cost was for seed and sowing (31.96\% to the total variable cost) which is consistent with the BBS report on The Productivity Survey of Turmeric Crop (BBS, 2013). Human labour was one of the most important and widely used inputs in the production process of turmeric farming. The sources of human labour were (1) family labour, for which no 
payment was made, and (2) hired labour, for which farmers had to pay in cash. To determine the cost of unpaid family labour, the opportunity cost principle was adopted. In this study, a man-day was considered to be 8 hour of work. The labour wage ranges with respect to nature of work, location, number of labourers required, and season. The average wage rate for turmeric farming was found to be Tk. 280 per day ranged from Tk. 250 to Tk.300 per day. Human labour is required in all the stages of operations. In this study, the average cost for human labour was calculated at Tk. 53332 per ha. The cost of intercultural operations and harvesting were calculated at Tk .13687per ha and Tk.15618 per ha respectively. Interest rate for agricultural loans was considered at the rate of seven percent.

Table 1 shows the share of variable costs of different costs items which reflects that, seed and seed sowing, intercultural operations and harvesting constitute around $70 \%$ of variable costs in turmeric farming which is consistent with the study of Karthik and Amarnath (2014) and BBS (2013 ${ }_{\mathrm{a}}$ ).

Rental value of land was considered as fixed cost of turmeric production. The average annual fixed cost for turmeric farming was Tk.15081per ha which accounted for $16.32 \%$ of total cost of production (Table 2).

As Table 2 shows, total costs of turmeric farming of all sampled farmers averaged Tk. 92431 per ha. The average shares of variable and fixed costs were calculated as $83.68 \%$ and $16.32 \%$ of the total cost of cultivation respectively.

Table 2. Total cost (Tk/ha) of turmeric cultivation in the study areas

\begin{tabular}{ll}
\hline Particulars & Amount $(\mathrm{Tk} / \mathrm{ha})$ \\
\hline Total variable cost & $77351(83.68 \%)$ \\
Total fixed cost & $15081(16.32 \%)$ \\
Total cost & $92432(100)$
\end{tabular}

Note: Figures in the parentheses are percent of total cost

\section{Farm Productivity}

\section{Turmeric and other crop productivity}

It was revealed that the annual average yield of turmeric was estimated at $6354.71 \mathrm{~kg} / \mathrm{ha}$ ranged from864.20 to $17119.34 \mathrm{~kg} / \mathrm{ha}$ (Table 3).As turmeric in the study areas is grown in Jhum land and most of the farmers follow traditional methods of cultivation where they use less capital investment, comparatively little or no fertilizer application which in turn in lower yield. These levels of yields also suggest that the average productivity of turmeric has increased in the study areas over recent years as Karna et al. (2010) found turmeric productivity as 5.928 tons per hectare indicating lower productivity. 
Table 3. Average yields (kg/ha) of turmeric and other crops grown in Jhum lands

\begin{tabular}{lc}
\hline Items/Crops & Average yield (t/ha) \\
\hline Turmeric & 6.35 \\
Rice & 1.27 \\
Okra & 0.11 \\
Cucumber & 0.29 \\
Long yard bean & 0.16 \\
Red amaranth & 0.03 \\
Bottle gourd & 0.53 \\
Pulse & 0.08 \\
Pumpkin & 0.53 \\
Ginger & 0.17 \\
Banana & 2.69 \\
Chili & 0.26 \\
Others & 0.19 \\
\hline
\end{tabular}

Source: Field survey (2015)

Responses concerning the reasons for increased turmeric productivity included an increased supply of quality seed/ knowledge on appropriate seed selection including improved varieties, technical support in turmeric cultivation, introducing training facilities, experience of farming, and low cost of seed, etc.

\section{Rice and other crops productivity}

Besides turmeric, hill farmers generally cultivate different types of crops on Jhum lands as mixed crops which are rice, spices and vegetables such as okra, cucumber, long yard bean, red amaranth, bottle gourd, pumpkin, ginger, chili and others. Table 3 further revealed that the average rice productivity was estimated at $1.3 \mathrm{ton} / \mathrm{ha}$. The rice productivity of the turmeric farmers $(1.27 \mathrm{t} / \mathrm{ha})$ are comparatively lower than the national average productivity of rice $(6.22 \mathrm{t} / \mathrm{ha})$ (BBS, 2010) which indicate that farmers have the great opportunity to improve rice productivity in the study areas by following better management practices and adopting HYVs of rice which are suitable in the hill area.

The average productivity of other crops were $0.11 \mathrm{t} / \mathrm{ha}, 0.29 \mathrm{t} / \mathrm{ha}, 0.16 \mathrm{t} / \mathrm{ha}$, $0.31 \mathrm{t} / \mathrm{ha}, 0.53 \mathrm{t} / \mathrm{ha}, 0.08 \mathrm{t} / \mathrm{ha}, 0.53 \mathrm{t} / \mathrm{ha}, 0.17 \mathrm{t} / \mathrm{ha}, 2.69 \mathrm{t} / \mathrm{ha}, 0.26 \mathrm{t} / \mathrm{ha}$ and $0.19 \mathrm{t} / \mathrm{ha}$ for okra, cucumber, long yard bean, red amaranth, bottle gourd, pulse, pumpkin, ginger, banana, chili and others respectively.

\section{Profitability of turmeric cultivation}

Gross revenue is affected by the level of production and its market price. Increasing farm productivity is one way to increase gross return. Gross return 
was calculated by multiplying the total amount [(seed, sold (fresh and dry) and consumed)] of production $(\mathrm{kg})$ by its market price $(\mathrm{Tk} . / \mathrm{kg})$.

The annual gross return of turmeric farming averaged at Tk. 205973 per hectare. Almost all the respondent farmers stated that their gross revenue had decreased as costs of turmeric farming had increased significantly, while the price of turmeric has not increased to a similar degree (Table 4).

At the farm level, net return is affected by the level of production, farm price and operating cost. Increase in farm productivity, reduction in production costs and increasing in average farm revenue are major measures to increase net return (Shang and Tisdell, 1997). Net return is calculated by deduction of total costs from gross return. As Table 4 shows, the annual net return per hectare of turmeric farms averaged Tk. 112139.

Table 4. Profitability of turmeric cultivation in the hill areas

\begin{tabular}{lc}
\hline Items & Amount \\
\hline Gross return (Tk/ha) & 205973 \\
Total cost (Tk/ha) & 93834 \\
Variable cost (Tk/ha) & 78753 \\
Gross margin (Tk/ha) & 127219 \\
Net return (Tk/ha) & 112139 \\
Rate of income (\%) & 54.44 \\
Benefit cost ratio (BCR) & \\
Over total cost & 2.20 \\
Over variable cost & 2.62 \\
\hline
\end{tabular}

Source: Calculated from field survey (2015)

Once the fixed investments have been made, farmers' production decision should be based on the expected returns or income above variable costs. The gross margin was calculated to be Tk. 127219 per ha in turmeric farming. It was observed that turmeric farms were able to generate positive returns to variable costs. This indicates that farmers are willing to pursue turmeric farming as the returns to variable costs are positive.

The rate of farm income is defined as net return divided by gross revenue multiplied by 100 . The rate of farm income averaged $54.44 \%$ in turmeric farming (Table 4).

Benefit cost ratio (BCR) or profitability index is defined as gross revenue divided by total costs of turmeric farming, which implies that a ratio of 1 means that the operation is a break even position. Table 4 shows that the BCR of sampled farmers averaged 2.20. This indicates that the turmeric farmers are able to 
recover Tk. 2.20 per Tk. 1 of investment. Turmeric farms with a BCR greater than 1 have greater benefits than costs as well as positive net benefits. It is observed that about $69 \%$ gross revenue came from turmeric in jhum cultivation (Table 5).

Table 5. Share of turmeric, other crops, vegetables and spices in gross revenue

\begin{tabular}{l|c}
\hline Revenue items & Amount (Tk/ha) \\
\hline Turmeric & $205973(68.70)$ \\
\hline Vegetables and other crops & $93834(31.30)$ \\
\hline
\end{tabular}

Figures in the parenthesis indicate percent of total

\section{Summary statistics of the variables included in the TE analysis}

Summary statistics of the sample data from the survey for the different variables in the stochastic frontier and inefficiency model, defined by Equations (4) and (5), is presented in Table 6. The table shows that considerable variation exists among the farmers in terms of production practices and the socioeconomic attainments. The average farm size was 0.33 ha ranging from 0.08 ha to $2.03 \mathrm{ha}$.

Seed (rhizome) has a major impact on production and the profitability of turmeric farm. In the study area, farmers are cultivating mostly the Pabna variety of turmeric as the demand for it is very high in the market and improved seed varieties like BARI Holud-1 (Dimla), BARI Holud-2 (Sinduri) and BARI Holud3 are not locally available. Farmers hand-pick the best turmeric and preserve it as seeds for the next season. They also purchase from other farmers if they need additional seeds to available own stocks. Since farmers produce turmeric as a mixed crop in Jhum lands they do not take into account the exact size of the land to determine the volume of seeds required. The average annual application of seed of turmeric was $634.08 \mathrm{~kg} / \mathrm{ha}$ which has considerable variation of turmeric farmers used. This finding is in line with the findings by Karna at el.(2010).

Fertilizer application (both organic and inorganic) is not based on the need of the soil, but rather on common practice. Except for some commercial production, most of the turmeric is produced by traditional farming practices where the farming knowledge derived from forefathers is used with no or less application of chemical fertilizer. On average, annual fertilization rate (organic and inorganic fertilizer) was $299.40 \mathrm{~kg} / \mathrm{ha}$ ranging from nil $\mathrm{kg} / \mathrm{ha}$ to $7135.80 \mathrm{~kg} / \mathrm{ha}$ in turmeric farm.

The average labour use is 156.76 man-days/ha ranging from 26.67 man-days/ha to 475.31 man-days/ha. For the land preparation male labour were used. Mostly female labours were working for hoeing and weeding.

The average age of farmers is 40 years ranging from 20 years to 83 years in turmeric farming. Average general education level is seemed to be level of primary ranging from illiterate to fourteen years of schooling. The average 
experience of farmers is 11 years ranging from 1 year to 42 years in turmeric farming.

Table 6. Summary statistics for variables in the stochastic frontier production functions for turmeric farming

\begin{tabular}{lccccc}
\hline \multicolumn{1}{c|}{ Variables } & Sample mean & $\begin{array}{c}\text { Standard } \\
\text { deviation }\end{array}$ & $\begin{array}{c}\text { Minimum } \\
\text { value }\end{array}$ & $\begin{array}{c}\text { Maximum } \\
\text { value }\end{array}$ \\
\hline $\begin{array}{l}\text { Geometric mean of total return } \\
\text { (Tk/ha) }\end{array}$ & 155958 & 51451 & 43519 & 372840 \\
Land (Ha) & 0.33 & 0.24 & 0.08 & 2.03 \\
Labour (Person-days/ha) & 156.76 & 63.31 & 26.67 & 475.31 \\
Seed (rhizome) (kg/ha) & 634.08 & 311.38 & 102.88 & 1975.31 \\
Fertilizer (kg/ha) & 299.40 & 759.48 & 0.00 & 7135.80 \\
Education (years of schooling) & 3.47 & 3.95 & 0 & 14 \\
Age (years) & 39.99 & 12.07 & 20 & 83 \\
Experience (years) & 11 & 6.87 & 1 & 42 \\
\hline
\end{tabular}

\section{Maximum Likelihood Estimates of Turmeric Cultivation}

The estimates of the stochastic frontier which shows the best practice performance, i.e., efficient use of the available technology, is presented in Table 7. The empirical results indicate that the elasticity of frontier (best practice) production with respect to farm size in turmeric farming was estimated to be 0.169 and is significant at $1 \%$ level. This indicates that, if the farm size is increased by one percent, then per hectare return from turmeric is estimated to decrease by $-0.169 \%$. In the turmeric farming, the elasticity of output with respect to labor, seed and fertilizer estimated to be positive and significant values of $0.004,0.187$, and 0.006 , respectively.

Farm size may have some influence on production of output, but the study encountered a negative sings for farm size in turmeric farming which are significant. Whether small lands are more productive or not is still dilemma. No definite answer is established as yet. Rahman (2005) found medium sized farm having the highest yield. The small farm get intensively input fed since additional of a small quantity of inputs adds very little to the overall cost that is not usually felt burdened. However, this small addition of inputs might get proportionately higher than the farm requires. It is likely that this might have happened beyond the knowledge of the farmers. On the contrary, larger land owners also seldom add inputs proportionately with the farm size because costs associated with the inputs application for bigger farm are high. Therefore, they are likely to add proportionately less than the farm requires. This feeling often results in proportionately higher input feeding for small farm and lower for larger farm. This is general scenario in particularly the turmeric farming system in hill under 
the existing economic conditions of the farmers. Appearance of a negative signs for the coefficient of farm size is therefore not surprising.

The value of the elasticity of seed implies that, if seed is increased by one percent, the turmeric return is estimated to increase by $0.187 \%$. The increase in the use of seed (rhizome) is expected to have a positive effect on turmeric production. The value of elasticity of fertilizer implies that if the use of fertilizer is increased by one percent, the turmeric return will be increased by 0.006 . The highest elasticity coefficient $(0.187)$ was estimated for seed (rhizome).

\section{Factors explaining inefficiency}

The results indicate that the farm specific variables included in the technical inefficiency model contribute significantly to the explanation of the technical inefficiencies (Table 7). In turmeric farming, education of the farmers, age and farm visit have positive significant impact on technical efficiency (negative impact on technical inefficiency).Results indicate that education significantly improves technical efficiency of turmeric farming, consistent with Karthick et al., (2013) for turmeric farms. The educated farmers are expected to follow the turmeric management practices properly, which might have led to higher efficiency for them.

The age coefficient is positive and significant with technical efficiency in turmeric farming which indicates that older farmers are more capable to take proper decisions regarding farm management practices as they have many years of practical experience. This confirms to the results obtained by Islam (2011).

The coefficient for number of farm visits by extension officers have positive impact on technical efficiency (negative impact on technical inefficiency) which indicates that an increase in the number of farm visits by extension officers decreases the inefficiency level of farmers in the study area. Thus, with the increase in farm visits their efficiency increases. This could be due to the fact that farmers that actively communicate with extension officer usually get information and benefits regarding input use and market prices of inputs and outputs.

It is evident from Table 7 that the estimate of $\gamma$ and $\sigma^{2}$ are large and significantly different from zero, indicating a good fit and the correctness of the specified distributional assumption. Moreover, the estimate of $\gamma$, which is the ratio of the variance of farm-specific technical efficiency to the total variance of output, is 0.81 ; and significant at $10 \%$ level. This suggests that the technical inefficiency effect is significant component of the total variability of turmeric output.

\section{Technical Efficiency Distribution}

The mean technical efficiency of turmeric farmers in Khagrachari is $82 \%$ ranging from $44 \%$ to $95 \%$ (Table 8). Unfortunately, not a single farm appears as fully technical 
efficient. The implication is that, on average, turmeric farming could generate $18 \%$ of the potential return by eliminating technical inefficiency, which is substantial.

Table7. Maximum likelihood estimates of the stochastic frontier production function of turmeric cultivation in Khagrachari district

\begin{tabular}{|c|c|c|c|c|}
\hline Variables & Parameters & Coefficients & Standard error & t-ratio \\
\hline \multicolumn{5}{|l|}{ Production frontier } \\
\hline Constant & $\beta 0$ & $10.667 * * *$ & 0.263 & 40.409 \\
\hline Land $\left(\mathrm{x}_{1}\right)$ & $\beta 1$ & $-0.169 * * *$ & 0.038 & -4.447 \\
\hline Labour $\left(\mathrm{x}_{2}\right)$ & $\beta 2$ & 0.004 & 0.017 & 0.232 \\
\hline Seed (rhizome) $\left(\mathrm{x}_{3}\right)$ & $\beta 3$ & $0.187 * * *$ & 0.041 & 4.599 \\
\hline Fertilizer $\left(\mathrm{x}_{4}\right)$ & $\beta 4$ & $0.006^{*}$ & 0.003 & 1.987 \\
\hline \multicolumn{5}{|l|}{ Inefficiency function } \\
\hline Constant & $\delta 0$ & -0.159 & 0.897 & -0.178 \\
\hline Age & $\delta 1$ & $-0.005^{* * *}$ & 0.011 & 5.121 \\
\hline Education & $\delta 2$ & $-0.019^{*}$ & 0.031 & -1.639 \\
\hline Experience & $\delta 3$ & 0.008 & 0.016 & 0.496 \\
\hline Training & $\delta 4$ & 0.719 & 0.763 & 0.943 \\
\hline Farm visit & $\delta 6$ & $-0.240^{*}$ & 0.274 & -1.876 \\
\hline \multicolumn{5}{|c|}{ Variance parameters } \\
\hline Sigma-squared & $\sigma^{2}$ & 0.208 & 0.191 & 1.088 \\
\hline Gamma & $\gamma$ & $0.808 * * *$ & 0.176 & 4.588 \\
\hline Log likelihood & & -14.333 & & \\
\hline Mean TE index & & 81.98 & & \\
\hline
\end{tabular}

Note: *** Significant at 1\%, ** Significant at 5\% and * Significant at $10 \%$

The indices of TE indicate that if the average turmeric farmers of the sample could achieve the TE level of its most efficient counterpart, then average turmeric farmers could increase their return by 14\% [1-(82/95)]. Similarly, the most technically inefficient turmeric farmers could increase the return by $46 \%$ [1-(44/95)], if he/she could increase the level of TE to his/her most efficient counterpart. These gains in return will increase their overall income and ensure better livelihood for the farmers.

About $4.67 \%$, of the turmeric farmers are producing at an efficiency level of less than $60 \%$ while $70.66 \%$ of the turmeric farmers are producing at an efficiency level of $80 \%$ and above, which are encouraging. The mean technical efficiency of turmeric farms is $81.98 \%$, which is quite similar to the estimates of average spices farms in Bangladesh and/or elsewhere in the world (Islam et al., 2011; Huq and Arshad, 2010). 
Table 8. Distribution of technical efficiency scores

\begin{tabular}{lc}
\hline Efficiency levels & Percentage \\
\hline$\leq 50$ & 1.34 \\
$50 \leq 60$ & 3.33 \\
$60 \leq 70$ & 6.67 \\
$70 \leq 80$ & 18.00 \\
$80 \leq 90$ & 53.33 \\
$90 \leq 100$ & 17.33 \\
Mean efficiency level & 81.98 \\
Minimum & 44.20 \\
Maximum & 95.19 \\
Standard deviation & 0.102 \\
Number of observations & 150 \\
\hline
\end{tabular}

\section{Constraints of Turmeric Cultivation}

A number of constraints were reported by respondents for turmeric farming, including lack of capital, insect, pest and disease attack, non-availability of modern verities, difficult to cultivate in slop of the land and problem of transportation, (Table 9). According to the survey, $61 \%$ of respondents identified inadequate finance as their single most important constraint. Costs of turmeric cultivation were reported to have increased significantly in recent years as a result of increased seed, fertilizer and labor costs. The prices of turmeric have decreased dramatically due to bumper yield has turned into a burden for farmers. Inadequate finance can therefore be a significant constraint. The proportion of respondents identifying pest and disease attack on turmeric and non-availability of improved seed varieties was 51\%and 13\% respectively. Only $9 \%$ and $7 \%$ of farmers reported problem of transport and cultivate in slop of the land to be the most important constraint, respectively.

Table 9. Constraints faced by turmeric growers

\begin{tabular}{lc}
\hline Key constraint & Grower $(n=150)$ \\
\hline Inadequate finance & $92(61 \%)$ \\
Insect, pest and disease attack & $76(51 \%)$ \\
Non-availability of improved/modern varieties & $19(13 \%)$ \\
Non-availability of transport & $9(6 \%)$ \\
Constraints to cultivate in slop of the land & $7(5 \%)$ \\
\hline
\end{tabular}

$\mathrm{n}$ sample size of turmeric farmers

\section{Conclusions and Policy Recommendations}

The profitability and technical efficiency of turmeric farming have been estimated by applying descriptive and Cobb-Douglas stochastic frontier 
production function analyses. Production of turmeric was profitable as farmers earned higher level of net returns from turmeric they produced. The gross margin was calculated to be Tk. 127219 per ha in turmeric farming. It is observed that turmeric farms were able to generate positive returns to variable costs. This indicates that farms are willing to pursue turmeric farming as the returns to variable costs are positive. The BCR of sampled farmers was 2.20. This indicates that the turmeric farmers are able to recover Tk. 2.20 per Tk. 1 of investment.

According to a stochastic frontier production function, seed (rhizome) and fertilizer showed significant positive effects on the turmeric production. From the factors that were assumed to affect technical efficiency, age, education and higher number of farm visits of extension officers increased the efficiency level of farms in the study areas. All these observations were significantly contribute the efficiency level.

According to the result obtained from Stochastic Frontier estimation, technical efficiency levels of turmeric farmers ranged from 44.20 to $95.19 \%$. Thus, there was a vast difference between technical efficiency levels of farmers even if they used the same level of inputs, though majority of the farmers were within the higher part of the range. The mean technical efficiency level of turmeric was $82 \%$ implying that a substantial $18 \%$ of the potential output from the farming system can be recovered by eliminating inefficiency with the present technology (technique) itself. Reductions in technical inefficiencies are unlikely to bring about large productivity gains. The estimates suggest that these efficiency gains could mainly come from production intensity and the improvement in the adoption of management practices and making better use of their inputs. Policies leading to the improvement of farm education would be favourable for improving the technical efficiency of farmers. While it is essential that farmers rotate their land for turmeric production every 3 years, this is rarely practiced leading to depletion of soil fertility, increasing soil erosion and reduced crop yields.

\section{References}

Ahluwalia, M.S. 1996. New economic policy and agriculture: Some reflections, Indian Journal of Agricultural Economics, 51(3): 412-426.

Aigner, D., K. Lovell and P. Schmidt. 1977. Formulation and estimation of stochastic frontier production function models. Journal of Economics, 6:21-27.

Alam, M.F., M.A. Khan and A.S.M.A.Huq.2011. Technical efficiency in tilapia farming of Bangladesh: a stochastic frontier production approach. Aquaculture International, 20: 619-634.

Backman, S., K.M.Z. Islam and J. Sumelius. 2011. Determinants of technical efficiency of rice farms in North-Central and North-Western regions in Bangladesh, The Journal of Developing Areas, 45: 73-94.

Battese, G.E. and T.J. Coelli. 1995. A model for technical inefficiency in a stochastic frontier production function for panel data. Empirical Economics, 20: 325-332. 
BBS. 2010. Bangladesh Bureau of Statistics. Statistics Division, Ministry of Planning, Government of the People's Republic of Bangladesh.

BBS. 2013. Bangladesh Bureau of Statistics. Report on The Productivity Survey of Turmeric Crop 2013, Productivity Assessment Survey of Different Agricultural Crops Programme, Statistics and Informatics Division (SID), Ministry of Planning, Government of the People's Republic of Bangladesh.

BBS. 2013. Bangladesh Bureau of Statistics. District Statistics 2011, Khagrachhari, Statistics and Informatics Division (SID), Ministry of Planning, Government of the People's Republic of Bangladesh.

BBS.2018. Bangladesh Bureau of Statistics. Annual estimate 2016-17, Statistical Year Book of Bangladesh

Coelli, T.J.1994.Manual guide of FRONTIER version 4.1 computer software package.

Coelli TJ, Prasadaro DS, Battese GE.1998. An introduction to efficiency and productivity analysis. Kluwer Academic Publishers.

Dillon, J.L. and J.B. Hardaker.1993. Farm Management Research for Small Farmer Development. Food and Agricultural Organization, Rome, Italy.

Farrell, M. 1957. The measurement of productive efficiency. Journal of the Royal Statistical Society, 102(3):253-281.

HuqA.S.M. A.and F. M. Arshad. 2010. Technical Efficiency of Chili Production. American Journal of Applied Sciences, 7 (2): 185-190.

Islam, M.S., K.M.M. Rahman and M.K. Hasan. 2011. Profitability and resource use efficiency of producing major spices in Bangladesh. The Bangladesh Journal of Agricultural Economics, 34 (1\&2):1-13.

Karna, N., R. Sarwar, and G.Mccarthy.2010. Value chains analysis final report, banana: Bandarban, Kagrachari and Rangamati Districts, Pineapple: Bandarban District Turmeric: Kagrachari District,Cht Value Chain Portfolio \#1.

Iinuma, M., K.R. Sharma and P.S. Leung.1999. Technical efficiency of carp pond culture in peninsula Malaysia: an application of stochastic frontier and technical inefficiency model. Aquaculture, 175: 199-213.

Meeusen, W, and V.D.Broeck.1977. Efficiency estimation from Cobb-Douglas production function with composite error. International Economic Review, 18(2):435-444.

Rahman, M.A. 2005. Profit efficiency of tilapia monoculture in TrishalUpazila of Mymensingh district. Unpublished Masters thesis, Bangabandhu Sheikh Mujibur Rahman Agricultural University, Gazipur, Bangladesh.

Shang, Y.C. and C.A. Tisdell. 1997. Economic decision making in sustainable aquaculture development. In: J.E. Bardach (ed.), Sustainable aquaculture. John Wiley and Sons, Inc. USA, pp. 127-148.

Karthik, V. and J.S. Amarnath.2014. An economic analysis of turmeric production in Tamil Nadu, India. Direct Research Journal of Agriculture and Food Science, 2 (6): 66-76.

Karthick, V., T. Alagumani and J.S. Amarnath.2013. Resource use efficiency and technical efficiency of turmeric production in Tamil Nadu-a stochastic frontier approach. Agricultural Economics Research Review, 26(1): 109-114. 